УДК 78.072.3

DOI https://doi.org/10.31723/2524-0447-2021-32-1-32

Мар'яна Михайлівна Вергун

ORCID: 0000-0001-9902-8473

викладач відділу теорії музики

КЗ Львівської обласної ради «Львівський музичний фаховий коледж

імені С. П. Людкевича»

mari-nella@ukr.net

\title{
ОПЕРНИЙ РЕПЕРТУАР ЯК ЧИННИК ІДЕОЛОГІЧНОГО ВПЛИВУ: МЕТАМОРФОЗИ ЛЬВІВСЬКОЇ ОПЕРИ 1939-1941 РОКІВ У СВІТЛІ МІСЦЕВОЇ ПРЕСИ
}

Мета роботи - дослідження музично-критичних публікацій у періодичних виданнях «окупаційного періоду», до яких належить преса малої амплітуди періодичності. Це періодичні видання, що виходили у Львові з вересня 1939 р. до червня 1941 р., а саме україномовні газети «Ленінська молодь» $i$ «Вільна Україна» та польськомовна “Сzегwопу sztandar”. Основною метою дослідження є систематизація та аналіз музично-критичних публікацій на шпальтах цієї періодики. Зокрема, аналіз діяльності Львівського театру опери та балету та дослідження оперного репертуару за період 1939-1941 рр. Методологія дослідження базується на контент- та консенс-аналізі - найчастіше застосовуваних методів у журналістикознавстві. Контент-аналіз є найбільш популярним у соціологічних та політологічних науках, однак усе частіше застосовуеться і в психології, літературо- та журналістикознавстві. Його використовують для вивчення джерел, близьких за структурою, але не систематизованих, що на перший погляд функціонують як невпорядковані текстові масиви. Такими джерелами найчастіше, власне, й виступають повідомлення у засобах масової інформації. Найголовнішим у консенс-аналізі є порівняння збігів та розбіжностей викладених y певних виданнях чи певних матеріалах. Отже, чим меншими $\epsilon$ їх відмінності, тим, відповідно, досягається більший консенсус.

Наукова новизна полягає у виявленні тенденцій музичної журналістики за умов ідеологічного тиску, а також висвітлення музичних подій щоденною пресою на зламі 1930-40-х років загалом. Зокрема, це дослідження базується на детальному аналізі оперного репертуару та оперного життя міста у світлі місиевої щоденної преси в період від вересня 1939 р. до червня 1941 р. Ця тема потребує майбутніх масштабних $i$ неупереджених досліджень, оскільки досі радянська спадщина в українській музичній журналістиці та критиці розглядалася доволі однобоко $i$ фактично не отримала осібного вивчення після здобуття незалежності.

(C) Вергун M. М., 2021 
Висновки. Музично-критичні публікації иього періоду дають усі підстави вважати мистецтво ідеологічною зброєю у руках тих, хто ним керує. Особливо якщо це масове мистецтво, де звичайний оперний репертуар виступає лише як засіб поступового впливу з метою виховати «нову людину» та побудувати «нове суспільство».

Ключові слова: музична критика, золотий вересень, ідеологія, сочреалізм, оперний репертуар, В. Барвінський.

Verhun Mariana Mykhaylivna, Lecturer at the Department of Music Theory of the Municipal Institution of Lviv Regional Council Stanislav Liudkevych Music Professional College of Lviv

Opera repertoire as a factor of ideological influence: Lviv Opera's metamorphoses of 1939-1941 in the light of the local press

Research objective is to study music-critical publications in periodicals of the "occupation period", which include small-amplitude press. These are periodicals published in Lviv from September 1939 to June 1941, the Ukrainian-language newspapers "Leninska Molod" and "Vilna Ukraina" and the Polish-language "Czerwony sztandar". The main goal of the study is systematization and analysis of music-critical publications. In particular, the analysis of the activities of the Lviv Opera and Ballet Theatre and the study of the opera repertoire for the period 1939-1941.

The methodology of the research is based on content and consensus analysis - the most commonly used methods in journalism. Content analysis is the most popular in the sociological and political sciences, but is increasingly used in psychology, literature and journalism. It is used to study sources that are similar in structure but unsystematized, which at first glance function as disordered text arrays. Such sources are often messages in the media. The most important thing in a consensus analysis is to compare the similarities and differences set out in certain publications or certain materials. Therefore, the smaller their differences, the greater the consensus.

The scientific novelty. Identify trends in music journalism under conditions of ideological pressure, and the coverage of musical events by the daily press at the turn of the 1930s and 1940s in general. In particular, this study is based on a detailed analysis of the opera repertoire and opera life of the city in the light of the local daily press in the period from September 1939 to June 1941. This topic requires future large-scale and unbiased research, as the Soviet heritage in Ukrainian music journalism and criticism was considered rather one-sided and, in fact, did not receive a separate study after independence.

Conclusions. Music-critical publications of this period give every reason to consider art an ideological weapon in the hands of those who control it. Especially if it is a mass art, where the usual opera repertoire acts only as a means of gradual influence in order to educate a "new person" and build a "new society".

Key words: music criticism, golden September, ideology, social realism, opera repertoire, $V$. Barvinsky. 
Актуальність дослідження. Звернутися до публікацій на музичну тему періоду 1939-1941 років у щоденних газетах «Ленінська молодь», «Вільна Україна» та "Czerwony sztandar" спонукала передовсім фактична неопрацьованість цього цінного фактологічного матеріалу. Сфера музично-критичної журналістики - це тема, яка потребує майбутніх масштабних і неупереджених досліджень, оскільки досі радянська спадщина в українській музичній журналістиці та критиці розглядалася доволі однобоко і фактично не отримала осібного вивчення після здобуття незалежності.

Мета статті - дослідження та детальний аналіз публікацій на музичну тематику, зокрема публікацій про спектаклі та інші мистецькі події у Львівському академічному театрі опери та балету у щоденній пресі Львова. Шляхом зіставлення тематичних пріоритетів у виданнях вибраного для аналізу періоду, а також підрахунку тематичних співпадінь прослідковуємо за всіма метаморфозами оперного репертуару Львівського академічного театру опери та балету, аналізуючи стилістику музично-критичних публікацій та впливи ідеологічних чинників на музичного критика зокрема.

Наукова новизна полягає у виявленні тенденцій музичної журналістики за умов ідеологічного тиску, а також висвітлення музичних подій щоденною пресою на зламі 1930-40-х років загалом.

Виклад основного матеріалу. Після приходу радянської влади до Львова 1939 року (так званого «золотого вересня») кардинально змінюється політична, соціальна та культурна діяльність міста. Одним із найважливіших засобів подальшого зміцнення своїх позицій та вирішення ідеологічних завдань новий режим вважав культуру. Для ефективної роботи у всіх культурних ділянках були фактично наново організовані творчі, мистецькі заклади та лабораторії, деякі з них просто реорганізовані (як, наприклад, Державна консерваторія, яка утворилася 1939 р. на базі трьох вищих музичних закладів Львова). У Львові та інших містах Західної України існували давні культурні традиції, були окремі мистецькі осередки, що відігравали дуже важливу роль у розвитку духовного життя суспільства. 3 приходом нової влади було перекреслено все набуте у сфері мистецтва до того часу. Саме 3 цієї причини так упевнено декларуються численні постанови щодо організації нових мистецьких та навчальних музичних закладів. 
На початок 1940 р. у Львові почали діяти такі інституціі: Львівська радіостанція (з музичним відділом), Симфонічний оркестр філармонії, Державна академічна капела «Трембіта», Львівський академічний театр опери та балету, Львівська консерваторія та деякі інші. Усі ці заклади та установи практично вже існували, проте новий уряд намагався створити «видимість» самого факту організації культурного життя у Львові та його позитивного впливу на розвиток мистецтва.

3 огляду на тематику представленого дослідження, детальніше зупиняємось на огляді мистецького життя, зокрема репертуару Львівського оперного театру, який був створений на основі ліквідованої попередньої театральної установи Театру Великого - та отримав назву Державний український театр опери та балету. 31934 р. був закритий через фінансову скруту. Про відновлення роботи театру пише Василь Барвінський у львівській пресі: «Передача радянською владою будинку Великого театру для користування театрові опери та балету для Львова має величезне мистецьке значення. Факт, що з львівської оперної сцени вперше в історії лунатиме українська мова. I все те стало дійсністю тільки тепер, за радянської влади, в рік звільнення Львова героїчною Червоною армією» [8].

Свою роботу «наново» театр розпочав з січня 1940 р., хоча комплектування солістів, хору, кордебалету й оркестру тривало аж до квітня 1940 р. Як писала 30 січня 1940 р. львівська газета «Вільна Україна», на той час у колектив театру було прийнято 350 осіб - солістів опери та балету, оркестрантів, режисерів, художників, повністю був укомплектований хор, ішло комплектування балетної трупи. Відкриття відбулося у вересні оперою Івана Дзержинського «Тихий Дон». Вочевидь, не випадково саме соцреалістичною оперою радянського композитора, натепер зовсім маргінального. Колектив очолив головний диригент опери М. Покровський. Окрім нього, працювали диригенти Юзеф Лерер та Якуб Мунд. Останній (єврейського походження) згодом був розстріляний німцями 1943 р. у Янівському концтаборі під Львовом, де перед тим керував табірним оркестром.

«Львівський оперний стає важливим осередком культурного життя краю, і слава про нього поширюється по всій Європі», - підкреслює А. Терещенко [5, с. 7]. Адже ще з часів його заснування (1900р.) тут співали відомі оперні виконавці, 
серед яких - Олександр Мишуга, Модест Менцинський, Соломія Крушельницька та інші.

Львівський театр опери та балету - установа, колектив котрої 1939 року складався із 215 осіб, а після напруженої розбудови у серпні наступного року налічував уже 500 осіб. Серед солістів переважали польські артисти - Францішка Слонєвська (Franciszka Słoniewska), Валерія Єнджеєвська (Waleria Jędrzejewska), Ромуальд Циганік (Romuald Cyganik), Францішек Бедлевіч (Franciszek Bedlewicz), Сжи Фітьо (Jerzy Fitio), Лешек Рейхан (Leszek Rejchan), Софія Чепєлювна (Zofia Czepielywna). Головним декоратором та художником-постановником театру був відомий львівський художник Фелікс Вигживальський (Feliks Wygrzywalski) [6, с. 111].

Також тут працювали режисери Олександр Улуханов, А. Лейн та В. Манзій, художники О. Хвостов (з Харкова), М. Ушин (з Ленінграда). Отже, серед числа солістів здебільшого збереглись місцеві виконавці, натомість режисери та художники-постановники були запрошені з інших міст Радянського Союзу. Серед них, зокрема, Олександр Улуханов - режисер та співак, представник московської школи. До роботи у Львові працював з антрепризами у Казані, Саратові, Києві, Тбілісі, Баку, Одесі, Санкт-Петербурзі; провадив режисерську діяльність у Києві, Петербурзі, Свердлові; у 30-х pp. - режисер «Російської опери» у Парижі. Тому театр володів величезним робочим та мистецьким складом, тут працювала «зіркова» плеяда 3 різних національних шкіл (польська, єврейська, українська тощо).

Як зазначає Гжегож Грицюк (Grzegorz Hryciuk) у своїй роботі "Polacy we Lwowie 1939-1944. Życie codzienne", «культурне життя - театральне і музичне - у Львові під час радянської окупації 1939-1941 pр. було оживлене. Радянська влада намагалася внести у цю ділянку відчуття певного позитиву і навіть розквіту» [6, с. 112]. Неабияку роль у цьому відігравала преса, котра з приходом радянської влади стала чи не основним знаряддям впливу на свідомість суспільства. Оскільки система політичної цензури стала всеохопною, випуск книжково-журнальної та газетної продукції без попередньої цензури та детальної перевірки заборонявся. Підтримку влади одержало лише обмежене коло авторів, які, намагаючись працювати в руслі канонів «соціалістичного реалізму», прийняли «радянську платформу». 3 огляду на це, у львівській пресі масово 
висвітлюється культурне життя міста. Філармонічні концерти, гастролі відомих виконавців, оперні прем'єри - повідомлення про ці події швидкими темпами друкуються на шпальтах періодичних видань. Музично-критичні публікації дуже часто зустрічаються у трьох львівських газетах, що існували на той час: україномовній «Ленінська молодь» та «Вільна Україна» та польськомовній "Czerwony sztandar".

Саме завдяки музично-критичним публікаціям та рецензіям на вистави можна прослідкувати за всіма метаморфозами оперного репертуару в період радянської окупації Львова. Детально опрацювавши публікації в пресі, наводимо список вистав, які були в репертуарі Львівського театру періоду від вересня 1939 р. до червня 1941 р., в хронологічному порядку:

1939 р. - «Пікова Дама» П. Чайковського; «Запорожець за Дунаєм» С. Гулак-Артемовського; Балет «Лауренція» О. Крейна;

1940 р. - «Тихий Дон» I. Дзержинського; «Травіата» Дж. Верді; «Євгеній Онєгін» П. Чайковського; балет «Дон Кіхот» Л. Мінкуса; «Мадам Батерфляй» і «Богема» Дж. Пуччіні.

1941 р. - «Наталка Полтавка» М. Лисенка в оригінальній редакції В. Костенка; балет «Червоний мак» Р. Глієра; «Кармен» Ж. Бізе; «Циганський барон» Й. Штрауса. Останньою роботою колективу театру мала стати постановка українського балету К. Данькевича «Лілея», про що повідомляла львівська газета «Вільна Україна» (за 20 червня 1941 р.). Проте iii прем'єру (до якої плідно й активно тривала підготовка) перервала війна. Окрім того, в одній із публікацій газети «Вільна Україна» про «відкриття оперного сезону у Львові» знаходимо затверджений план репертуару на 1940-1941 pp. Серед не поставлених, але запланованих перед війною спектаклів, є опери «Тарас Бульба» М. Лисенка, «Аїда» Дж. Верді, «Корневільські дзвони» Робера Планкетта, «Мадам Анго» Шарля Лекока, музику до драми Островського «Снігуронька» за Чайковським, сценічна постановка драми «Пер Гюнт» Е. Гріга.

Багатий репертуар театру був наповнений різноманіттям національних шкіл та контрастом жанрів - від легких оперет і балетів до лірико-драматичних опер. Однак червоною ниткою в репертуарі проходять опери у стилі соцреалізму (як, наприклад, «Тихий Дон»), радянські балети про нерівність класових верств населення, буржуазію і т.п. Якраз у цьому полягала 
найбільша функція ідеологічної машини у сфері культури заангажованість суспільства масовим мистецтвом радянського спрямування на новоопанованих територіях, для публіки, котрій потрібні були нові ідеологічні переконання.

Як було зазначено вище, всі постановки львівської опери одразу ж фіксувались у вигляді розширених публікацій у пресі: анотацій-повідомлень про майбутню прем'єру та рецензію на неї. Найбільший парадокс полягає у тому, що саме «радянські» опери та балети отримували високопрофесійну оцінку в пресі, часто з кількома статтями, написаними професійними критиками. Найчастіше в ролі останнього виступав композитор, директор Львівської консерваторії В. Барвінський. Наприклад, прем'єрі опери «Тихий Дон» Івана Дзержинського в газеті «Вільна Україна» було присвячено чотири великі статті різних авторів (на двох сторінках номера). Серед них - масштабна фахова стаття В. Барвінського. Невипадково Львівський театр розпочав свій концертний сезон цією оперою, адже це твір, в якому радянський композитор Іван Дзержинський яскраво втілив основні постулати панівного на той час стилю - соцреалізму. «Тихий Дон» - перша опера композитора, за рекомендацією Д. Шостаковича була включена в план Ленінградського малого театру опери та балету, в жовтні 1935 р. поставлена і незабаром увійшла до репертуару багатьох музичних театрів країни. Перше видання клавіру вийшло з присвятою опери Д. Шостаковичу. У разі повторного його видання I. Дзержинський зняв присвяту під впливом редакційної статті «Сумбур замість музики» в газеті «Правда».

Як зазначає А. Терещенко, з часу іiі прем'єри в Малому театрі «опера «Тихий Дон» ставиться в багатьох театрах країни, маніфестуючи реалістичні засади сучасної опери, «нову інтонацію», почуту в живому плині народнопісенної мови. Вистава, підготовлена молодою трупою львівського театру, пройшла з успіхом і мала гучний резонанс» [5, с. 10-11]. Творчий склад опери, в основному, залишається той самий, що і в попередніх постановках. Окрім уже знайомих прізвищ М. Трегубова, А. Улуханова, М. Покровського, Ф. Слоневської, Ф. Бедлевича, Л. Ландау, Р. Циганіка - автор рецензії А. Лєв ("Czerwony sztandar") наголошує на хорошій роботі декоратора Хвостова. Загалом, надруковані доволі позитивні та схвальні рецензії, що свідчать про великий успіх опери. Тільки В. Барвінський у своїй статті доволі недвозначно назвав 
iї «повноцінним спектаклем» [9]. Очевидно, що для рецензування творів на подібну тематику потребували найбільш талановитих критиків, майстрів слова, котрі мають авторитетну думку, а також посідають важливе місце у суспільному житті. Василь Барвінський як відомий композитор, музичний діяч, директор Львівської консерваторії (на той час) успішно виконав місію музичного критика, продемонструвавши всю майстерність свого пера. ««Тихий Дон» - це одна із найбільш вдалих спроб дати класичну по формі радянську оперу. Їі лібрето основане на тлі роману Шолохова, під иією жк назвою, в якому особиста трагедія героїв тісно в яжсеться з великими історичними подіями, які до основ струснули старий світ гніту і експлуатаuіï» [9]. Дуже влучно і коректно він критикує музичну сторону опери, даючи слушні та обгрунтовані зауваження: «Сама музична мова не посідає ще якихсь виразних індивідуальних рис $i$ не претендує на новаторські тенденції. Проте вже в цій першій спробі молодого композитора відчуваємо інколи новий колорит, так характерний для кращих масових радянських пісень» [9].

Подібне завдання, мабуть, було у Барвінського під час написання рецензії на постановку балету Людвіга Мінкуса «Дон Кіхот». Найбільша складність представленої статті полягала насамперед у майстерності дати не занадто критичну, позитивну оцінку на постановку цього балету. Про сумнівність художної якості музичного полотна В. Барвінський пише відкрито, проте коректно: «Надавати музиці Мінкуса, написаній для балету «Дон Кіхот», якогось мистецького серйозного значення не слід, бо ні формою, ні змістом ці поодинокі, майже не зв 'язні між собою музичні номери, не викликають зацікавлення» [11]. Тим не менше, у двох інших рецензіях на цю постановку в газетах «Ленінська молодь» та “Czerwony sztandar" ніхто 3 авторів не насмілювався висловлювати саме такі думки. А навпаки, були надто щедрими у своїх судженнях, позитивно формулюючи музично-критичну оцінку на роботу колективу та й музику композитора загалом. В. Барвінський же акцентує свою увагу на величезному значенні іншого факту. Музична сторона твору набула якіснішої форми у редакції композитора Ю. Кофлера, котрий «зумів усі поодинокі музичні номери зв'язати в більш органічно-злитий твір, написавщи до нього пролог і епілог та кілька вставок» [11].

Важливою подією для Львова став приїзд композитора Райнгольда Глієра. Про це йдеться в рецензії на постановку 
його балету «Червоний мак». «Ім'я композитора Глієра є відоме $i$ широко популярне у всьому Радянському Союзі. Наше місто недавно мало честь гостити його у себе, $i$ пізнати його як диригента і композитора симфонічної музики. "Червоний мак» (1926-27 рр.) - перший балет, оснований на радянських мотивах, перша вдала спроба створення нової форми радянського балету» [7].

Про факт приїзду Р. Глієра до Львова пише і В. Барвінський. У своїй рецензії на постановку його балету композитор говорить, що «це перша вдала спроба створити балет на радянську тематику» [10]. А найкращим репрезентантом є вислів, який висвітлює великий вплив ідеології на митця: «3 новим розмахом та розквітом музичної культури Львова, що почався 3 дня встановлення радянської влади на землях Західної України, ряди видатних музичних діячів, композиторів та виконавців помітно зросли» [10].

Розлога публікація В. Барвінського про перебування Р. Глієра у Львові та його балет «Червоний мак», надрукована у двох номерах газети «Вільна Україна», знайомить львівського читача із постаттю відомого російського композитора та його творчістю. Барвінський, насправді, в деталях лаконічно описує життєвий і творчий шлях Р. Глієра та його досягнення; наголошує на великій значимості його перебування у Львові, а особливо виконання балету «Червоний мак» на сцені львівського театру. Сама ж рецензія на прем'єрну постановку балету написана іншим автором.

Висновки. Прихід нової влади до Львова у вересні 1939 р. позначився неабиякою зміною культурного, соціального та політичного життя міста. Цікавими є перебудови в культурному житті міста і впровадження нових постанов щодо культурного та освітнього процесу, оскільки це позначилося на різкій зміні в ідеології та естетиці цих сфер функціонування суспільства. Місто мало якнайшвидше стати радянським Львовом. Поступово розмиваються всі сліди будь-якої національної приналежності.

Тим не менше, у мистецьких сферах панує творча атмосфера - з успіхами проходять концерти та спектаклі, які збирають чисельну і вдячну публіку. Отже, реорганізований театр опери та балету показав активну плідну діяльність у період з 1939 до 1941 рр. У театрі були зроблені постановки таких опер, як «Пікова Дама» П. Чайковського, «Запорожець за 
Дунаєм» С. Гулак-Артемовського, «Травіата» Дж. Верді, «Мадам Батерфляй» і «Богема» Дж. Пуччіні, «Наталка Полтавка» М. Лисенка та ін.; і балетів «Червоний мак» Р. Глієра, «Лауренція» О. Крейна, «Дон Кіхот» Л. Мінкуса та ін. Важливою подією також став приїзд до Львова композитора Р. Глієра та інших музикантів і співаків. Усі культурні події одразу знаходили своє відображення у пресі, про що свідчать численні музично-критичні публікації на сторінках наявних у цей період газет.

Проте подібні публікації дають усі підстави вважати мистецтво ідеологічною зброєю у руках тих, хто ним керує. Особливо якщо це масове мистецтво, де звичайний оперний репертуар виступає лише як засіб поступового впливу з метою виховати «нову людину» та побудувати «нове суспільство». В цьому неабияк допомагає преса та публікації в ній. Цінні свідчення того часу потребують сучасного опису і характеристик з позицій сучасного бачення.

\section{СПИСОК ЛІТЕРАТУРИ}

1. Аверьянов Л.Я. Контент-анализ : учебное пособие для студентов, преподавателей филологических факультетов высших учебных заведений. Москва : КноРус, 2009. 450 с.

2. Білавич Д. Музично-критична діяльність В. Барвінського (на матеріалах фондів музею С. Крушельницької у Львові). В. Барвінський в контексті європейської музичної культури. Тернопіль, 2003. C. $139-144$.

3. Курилишин К. Українська легальна преса періоду німецької окупації (1939-1944рр.): Історико-бібліографічне дослідження. НАН України. ЛНБ ім. В. Стефаника. Відділ україніки / Наук. ред.-консульт. М.М. Романюк ; Відп. ред. Л.В. Сніцарчук. У 2 т. Львів, 2007. T. 1: A-M. 639 c.

4. Потятиник Б.В. Тоталітарна журналістика: Текст лекцій. Львів : Ред.-вид. відділ, 1992. 80 с.

5. Терещенко А.К. Львівський державний академічний театр опери та балету імені Івана Франка. Київ : Музична Україна, 1989. 208 c.

6. Hryciuk G. Polacy we Lwowie 1939-1944. Życie codzienne. Warszaw a: Książka I Wiedza, 2000. 430 s.

7. Аквілєв А. «Червоний мак». «Вільна Україна». 1941. № 72.27 березня.

8. Барвінський В. Велика культурна подія. «Вільна Україна». 1940. № 121. 26 травня.

9. Барвінський В. Повноцінний спектакль. «Вільна Украӥна». 1940. № 224. 24 вересня. 
10. Барвінський В. Композитор Р.М. Глієр у Львові. «Вільна Україна». 1941. № 40. 18 лютого.

11. Барвінський В. «Дон Кіхот». У Львівському державному театрі опери та балету. «Вільна Україна». 1940. № 257. 1 листопада.

12. Lew A. "Cichy Don". Premjera w Lwowskim Państwowym Teatrze Opery i Baletu. "Czerwony sztandar”. 1940. № 308. 25 września.

13. Mantel W. Czerwony mak (z teatru opery i baletu). "Czerwony sztandar”. 1941. № 70.

\section{REFERENCES}

1. Averyanov L. Content analysis: study guide for students, teachers, philological faculties of higher educational institutions. Moskva: KnoRus, 2009.

2. Bilavuch D. Music-critical activity of V. Barvinsky (on the materials of the funds of the museum of S. Krushelnytska in Lviv). V. Barvinsky in the context of European musical culture. 2003.

3. Kurylyshyn K. Ukrainian legal press of the period of German occupation (1939-1944): Historical and bibliographic research. National Academy of Sciences. Lviv National Library named after V. Stefanyk. Science ed.-consultant M.Romaniuk; Resp. ed. L. Snitsarchuk. In 2 vol. Lviv, 2007. Vol. 1.

4. Potiatynyk B. Totalitarian journalism. Text of lectures. Lviv: editorial and publishing department. 1992.

5. Tereshchenko A. Lviv State Academic Opera and Ballet Theater named after Ivan Franko. Kyiv: Musical Ukraine, 1989.

6. Hryciuk G. Polacy we Lwowie 1939-1944. Życie codzienne. Warszawa: Książka I Wiedza, 2000.

7. Akvilev A. "Red Poppy". "Free Ukraine". 1941. No. 72. March 27.

8. Barvinsky V. A great cultural event. "Free Ukraine”. 1940. No. 121. May 26.

9. Barvinsky V. A full-fledged performance. "Free Ukraine”. 1940. No. 224. September 24.

10. Barvinsky V. Composer R. Glier in Lviv. "Free Ukraine". 1941. No. 40. February 18.

11. Barvinsky V. "Don Quixote". At the Lviv State Opera and Ballet Theater. "Free Ukraine”. 1940. No. 257. November 1.

12. Lew A. "Cichy Don". Premjera w Lwowskim Państwowym Teatrze Opery i Baletu. "Czerwony sztandar". 1940. No. 308. 25 września.

13. W. Mantel. Czerwony mak (z teatru opery i baletu). "Czerwony sztandar”. 1941. No. 70. 